\title{
The Role of Soil Amendments on Population Dynamics of Insect Pests, Growth Parameters and Yield of Eggplant, Solanum melongena (L.) Moench
}

\author{
P. K. Baidoo ${ }^{1}$, M. B. Mochiah ${ }^{2}$, D. Asare ${ }^{1} \&$ A. A. Sefah ${ }^{1}$ \\ ${ }^{1}$ Department of Theoretical and Applied Biology, Kwame Nkrumah University of Science and Technology, \\ Kumasi, Ghana \\ ${ }^{2}$ Entomology Section, CSIR-Crops Research Institute, P. O. Box 3785, Kwadaso, Kumasi, Ghana \\ Correspondence: P. K. Baidoo, Department of Theoretical and Applied Biology, Kwame Nkrumah University of \\ Science and Technology, Kumasi, Ghana.E-mail:pkbaidoo2002@yahoo.com
}

\author{
Received: August 26, 2017 Accepted: September 23, 2017 Online Published: October 12, 2017 \\ doi:10.5539/sar.v7n1p7 \\ URL: https://doi.org/10.5539/sar.v7n1p7
}

\begin{abstract}
Loss of soil fertility as a result of continuous cropping on the same piece of land has necessitated the need to improve soil fertility for better crop yields. Inorganic and organic fertilizers have been used to improve soil fertility, however, excessive use of soil amendments improve vegetative growth of plants thereby attracting large numbers of insect pests. Cow dung and poultry droppings were used as soil amendments in a field experiment using eggplant Solanum melongena. The effects of these organic manures were compared with inorganic fertilizer (NPK) and a control where there was no application of soil amendment in a randomized complete block design with 3 replicates. Parameters studied were pests' and their numbers, plant height, number of leaves per plant, leaf area, stem girth and yield. The major insect pests identified on the plant were Bemisia tabaci, Aphis gossypii, Leucinodes orbonalis and Eublemma olivacea. Bemisia tabaci and Aphis gossypii scores were significantly larger on cow dung and poultry manure plots. Leucinodes orbonalis and Eublemma olivacea numbers were not significantly different on the treated and control plots. Mean plant height, number of leaves and yield differed significantly among the soil amended plots. Even though soil amendments improve the nutrient content of the soil and the yield of crops it could lead to increase in pests numbers and damage caused to plants.
\end{abstract}

Keywords: Aphis gossypii, Bemisia tabaci, insecticide, manure, stem girth, transplanting

\section{Introduction}

Eggplant (Solanum melongena L.) also known as garden egg is one of the important vegetable crops widely cultivated and consumed in many countries. It is cultivated together with other vegetables such as pepper, tomato and okra (Ibekwe et al., 2014) but may also be cultivated in a monocropping system. The fruits of eggplants are essential sources of carbohydrates, vitamins, proteins and mineral salts (Shirley, 2000). Its consumption has increased in developing countries like Ghana due to population growth. Raw eggplant is composed of $92 \%$ water, $6 \%$ carbohydrates, $1 \%$ protein and negligible fat (San Jose et al., 2014) and small quantities of thiamine, niacin, riboflavin and iron (Siemonsma and Piluek, 1994).

Cultivation of vegetable crops is hampered by a number of constraints such as low soil fertility, insufficient rainfall and the incidence of diseases and pests. Insect pests are the most important limiting factor to increased production of eggplant and other vegetable crops. One hundred and forty six insect species have been documented to be pests of eggplant (Critchley, 1995).

The use of organic and inorganic fertilizers has impacted positively on the yield of eggplant; however, dependence on chemical fertilizers for increased crop production may not always be feasible (Insaidoo and Quarshie-Sam, 2007). The fact that chemical fertilizers are expensive and may not be readily available to the small scale farmer is a drawback to increased crop production. The importance of eggplant in terms of its nutritional value and as an export crop is negatively affected by a number of insect pests which attack the plant at various stages of growth. These include piercing and sucking insects such as whiteflies, aphids and thrips and plant defoliators such as the grasshopper, Zonocerus vareigatus and Acraea peneleos (Owusu-Ansah et al., 
2001). The most destructive pest of eggplant is the fruit and shoot borer Leucinodes orbonalis which can cause yield reduction up to 70\% (Van Steenwyk and Barnett, 1985).The larvae of eggplant fruit and shoot borer make holes in the tender shoots resulting in withering of the plant. Larvae feed inside the fruit causing severe economic damage. Other major pests of eggplant include aphid, Aphis gossypii (Goggin, 2007), the spotted beetle, Epilachna dodecastigana (Wiedemann), (Alagarmalai et al., 2014) and the leafhopper, Amarasca devastans (Van Steenwyk and Barnett, 1985).

In order to increase food production for the ever-increasing human population, there is the need to reduce the effects of insect pests on cultivated crops and improve the nutrient content of the soil. Chemical fertilizers, when applied to the soil increase agricultural productivity. The commonly deficient nutrient in the soil is nitrogen and its application in the form of nitrates leads to increased yield. High photosynthetic activity, dark green leaves and healthy vegetative growth are associated with adequate nitrogen supply (Jahn et al., 2004). The continuous use of chemical fertilizer as soil amendment may not be the most environmentally preferred option to improve soil fertility in Ghana and other developing countries. This is due to its cost, the fact that it may not be readily available and on time and the problem of run-off of excess fertilizer into water bodies.

The alternative to the use of chemical fertilizer is the application of organic fertilizer. Poultry manure and waste from other farm animals is the alternative to increasing the nutrient content of the soil (Dauda, 2008) for plant growth and increased food production. Poultry manure has been used over the years as a source of plant nutrients to increase soil productivity, soil organic carbon, microorganisms and yield of crops (Beckmann, 1973). Organic manures are less expensive, but they provide the plant with good sources of nitrates and phosphates which are the main constituents of poultry manure (Rahman, 2000). Other important elements such as calcium, magnesium and sodium are present in poultry manure (Dauda et al., 2005). According to Aliyu et al. (1992), the extensive use of inorganic fertilizer has a depressing effect on yield, reducing the number of fruits, delaying and depressing fruit setting leading to heavy vegetative growth.

Application of inorganic fertilizer imposes a huge financial burden on farmers, with its attendant negative effects. The current study evaluated poultry manure and cow dung as soil amendments in the management of pests of eggplant and how these affected growth parameters and yield of the plant.

\section{Materials Methods}

\subsection{Study Area}

The experiment was conducted on an experimental farm of the Department of Theoretical and Applied Biology, Kwame Nkrumah University of Science and Technology, Kumasi from December 2016 to March 2017. The area lies within latitude $06^{\circ} 41 \mathrm{~N}$ and longitude $01^{\circ} 33 \mathrm{~W}$ and in the forest region of Ghana. The soil type is intermediate between sand and loam and is well drained. Average annual precipitation is $166 \mathrm{~cm}$; relative humidity during the study was $69.3 \%$ to $76.1 \%$. Average daily minimum and maximum air temperatures range from $21-23{ }^{\circ} \mathrm{C}$ and $31-34{ }^{\circ} \mathrm{C}$ respectively (Mochiah et al., 2011).

\subsection{Land Preparation}

The entire field was cleared of weeds and the soil was turned over using a hoe, a local farming implement. Twelve plots each measuring $5 \mathrm{~m} \times 1.5 \mathrm{~m}$ were laid out, with $0.5 \mathrm{~m}$ alley between 2 plots for easy movement.

\subsection{Preparation of Organic Manure}

Poultry droppings and cow dung were obtained from the Animal Farm of the Animal Science Department. Each was heaped in the open separately and allowed to decompose for 4 weeks before they were used.

\subsection{Nursing, Transplanting and Application of Soil Amendments}

Eggplant, S. melongena seeds (var. Nsuroawia), a local variety obtained from the Horticultural Division, CSIR-Crops Research Institute of Council for Scientific and Industrial Research (CSIR) were sown on seed bed and covered with palm fronds, which were removed after germination. Seedlings were watered daily in the evening until ready for transplanting, after 4 weeks of germination. The experiment was conducted in a randomized complete block design, with 4 treatments and 3 replications. The treatments were: poultry manure, cow dung, NPK (15-15-15) compound fertilizer and a control in which there was no application. Transplanting of eggplant seedlings was done 4 weeks after seed germination. On each plot there were 3 columns with 10 plants in each column. Within each column planting interval was $50 \mathrm{~cm}$. The interval between 2 columns was 50 $\mathrm{cm}$. Two weeks after transplanting, application of soil amendments was done. Chemical fertilizer was applied at a rate of $10 \mathrm{~g} / \mathrm{plant}$ and this was done by putting it into small hole about $10 \mathrm{~cm}$ from the base of the plant. In the case of organic manure, $50 \mathrm{~g}$ each of poultry droppings and cow dung was applied around the stem of the plant 
in their respective plots. The control plots remained untreated.

\subsection{Data Collection}

\subsubsection{Insect Pest Enumeration}

This commenced 1 week after application of soil amendments and continued weekly till harvest. Sampling and data collection were carried out between 6 am and 8 am when the insects were least active. At each sampling and on each plot, plants were carefully examined for signs of pest infestation. Aphids and whiteflies were assessed using a visual scoring scale with regard to colony size: 0-No aphids or whiteflies; 1-Few individuals; 2-Few isolated small colonies; 3- large isolated colonies; 4-large isolated colonies; 5-Large continuous colonies (Salifu, 1982).Other insect pests were collected into specimen bottles and taken to the laboratory for identification and counting. This was done weekly until harvest.

\subsubsection{Growth Parameters}

\subsubsection{Leaf Area}

Ten weeks after transplanting; 3 leaves from each sampled plant were plucked and used to determine leaf area. Digital image protocol by O'Neal et al. (2002) was used to measure leaf area by using a desk-top scanner and public domain software for measuring existing leaf area.

\subsubsection{Plant Height}

Plant height was measured using a meter rule; this was taken from the base of the stem to the uppermost canopy of the leaves. The heights of 5 plants were measured and the means were calculated and recorded.

\subsubsection{Total Number of Leaves}

Total number of leaves of the 5 sampled plants was counted and the mean for each treatment was calculated and recorded.

\subsubsection{Stem Girth}

The diameter of each of the sampled plant was measured using a micrometer screw gauge at weekly intervals for 5 weeks and the means were calculated.

\subsubsection{Yield Assessment}

Matured fruits were harvested twice a week, placed in labelled envelopes and weighed. This was done for 3 weeks and the mean weight per week for each treatment was calculated.

\subsection{Data Analysis}

Data obtained were analyzed using the Graph pad prism (version 6.0). Analysis of variance was performed on the parameters studied. Where the differences were significant, the means were separated using Turkeys' multiple comparison test at $95 \%$ confidence level.

\section{Results}

\subsection{Insect Pests of Eggplant}

The major insect pests identified on eggplant during the study period were: the whitefly, Bemisia tabaci Genn., aphid, Aphis gossypii Glover, spotted beetle, Epilachna dodecastigina, (Wied.) the shoot and fruit borer, Leucinodes orbonalis Guinee, Brinjal leafroller Eublemma olivacea (Walker) and the leaf hopper, Amrasca devastans (Dist.).

\subsubsection{Bemisia tabaci}

Eggplants grown on soil amended with poultry manure recorded the largest mean score, while the control plots recorded the least score. Significant differences in B. tabaci scores were recorded on eggplants grown on the nutrient-amended soil and the control $(\mathrm{P}=0.03)$, however, no significant differences in $B$. tabaci scores were observed on eggplants grown on the nutrient-amended plots (Table 1).

\subsubsection{Aphis gossypii}

Aphis gossypii scores ranged from 0.33 on the control plots to 1.71 on the cow dung-amended soil. Significant differences in A.gossypii score existed between the treated plots and the control; however, there were no significant differences between poultry manure and cow dung-amended soils (Table 1). 
Table1. Effects of soil amendments on mean population of insect pests of egg plant (Solanum melongena)

\begin{tabular}{llllll}
\hline Treatment & $\begin{array}{l}\text { Bemisia } \\
\text { tabaci }\end{array}$ & $\begin{array}{l}\text { Aphis } \\
\text { gossypii }\end{array}$ & $\begin{array}{l}\text { Eublemma } \\
\text { olivacea }\end{array}$ & $\begin{array}{l}\text { Leucinodes } \\
\text { orbonalis }\end{array}$ & $\begin{array}{l}\text { Amrasca } \\
\text { devastans }\end{array}$ \\
\hline Control & $1.03 \pm 0.80^{\mathrm{a}}$ & $0.33 \pm 0.02^{\mathrm{a}}$ & 0.00 & 0.00 & $1.28 \pm 0.80^{\mathrm{a}}$ \\
Cow dung & $1.73 \pm 0.80^{\mathrm{b}}$ & $1.71 \pm 0.23^{\mathrm{b}}$ & $1.42 \pm 0.06^{\mathrm{a}}$ & $0.28 \pm 0.01^{\mathrm{a}}$ & $3.85 \pm 0.96^{\mathrm{b}}$ \\
Poultry manure & $1.73 \pm 0.14^{\mathrm{b}}$ & $1.13 \pm 0.08^{\mathrm{b}}$ & $8.85 \pm 3.10^{\mathrm{a}}$ & $0.42 \pm 0.02^{\mathrm{a}}$ & $7.01 \pm 1.27^{\mathrm{b}}$ \\
NPK & $1.63 \pm 0.10^{\mathrm{b}}$ & $0.47 \pm 0.03^{\mathrm{a}}$ & 0.00 & 0.00 & $4.28 \pm 1.40^{\mathrm{b}}$ \\
P value & 0.003 & 0.002 & 0.067 & 0.196 & 0.007 \\
\hline
\end{tabular}

Within columns means with the same letter are not significantly different $(\mathrm{P}>0.05)$.

\subsubsection{Eublemma olivacea}

This insect was totally absent on the control plots as well as the NPK-treated plots, and present only on poultry manure (8.85) and cow dung amended soil (1.42).

\subsubsection{Leucinodes orbonalis}

Very small numbers of this pest was encountered on eggplants grown on plots amended with poultry as well as cow dung plots.

\subsubsection{Amrasca devastans}

The population of A. devastans was low on eggplant. It ranged from a mean of 1.28 on the control plots to 7.01 on poultry manure-amended soil. The differences were highly significant. There were no significant differences in A. devastans numbers on eggplants grown with the different soil amendments.

\subsection{Influence of Soil Amendments on Growth Parameters of Eggplant}

\subsubsection{Plant Height}

Plant height ranged from $50.81 \mathrm{~cm}$ on the control plots to $63.14 \mathrm{~cm}$ on the cow dung-amended soil (Table 2). The observed differences were significant. Mean plant height on NPK-treated plots and poultry manure-treated plots did not differ significantly, but were significantly shorter than plants grown on the cow dung amended soil.

Table 2. Effects of soil amendments on growth parameters and yield of egg plant (Solanum melongena)

\begin{tabular}{llllll}
\hline Treatment & Plant height $(\mathrm{cm})$ & Number of leaves & Stem girth $(\mathrm{mm})$ & Leaf Area $\left(\mathrm{cm}^{2}\right)$ & Yield $(\mathrm{kg})$ \\
\hline Control & $50.81 \pm 4.40^{\mathrm{a}}$ & $27.1 \pm 8.35^{\mathrm{a}}$ & $12.9 \pm 1.2^{\mathrm{a}}$ & $129.4 \pm 25.1^{\mathrm{a}}$ & $0.99 \pm 0.06^{\mathrm{a}}$ \\
Cow dung & $63.14 \pm 5.80^{\mathrm{b}}$ & $38.3 \pm 11.1^{\mathrm{b}}$ & $15.5 \pm 1.6^{\mathrm{b}}$ & $203.4 \pm 70.9^{\mathrm{a}}$ & $7.09 \pm 2.50^{\mathrm{b}}$ \\
Poultry manure & $60.31 \pm 7.60^{\mathrm{c}}$ & $35.6 \pm 11.8^{\mathrm{a}}$ & $16.1 \pm 1.7^{\mathrm{b}}$ & $184.4 \pm 57.8^{\mathrm{a}}$ & $3.51 \pm 1.20^{\mathrm{c}}$ \\
NPK & $59.17 \pm 7.55^{\mathrm{c}}$ & $30.8 \pm 10.3^{\mathrm{a}}$ & $16.2 \pm 1.8^{\mathrm{b}}$ & $190.7 \pm 66.1^{\mathrm{a}}$ & $4.24 \pm 0.76^{\mathrm{c}}$ \\
P value & 0.009 & 0.012 & 0.005 & 0.358 & 0.012 \\
\hline
\end{tabular}

\subsubsection{Number of Leaves and Leaf Area}

Eggplants grown on cow dung-amended soil recorded the largest number of leaves, whilst the control plants recorded the least number of leaves; the differences were significant. Plants grown on poultry manure soil recorded significantly larger number of leaves than those grown on cow dung-amended soil. Mean leaf area of plants grown on amended soils and control did not differ significantly $(\mathrm{P}=0.358)$.

\subsubsection{Stem Girth}

Plants grown on nutrient-amended soils recorded significantly larger stem girth than the control. It ranged from $12.9 \mathrm{~mm}$ on the control plots to $16.2 \mathrm{~mm}$ on plots amended with chemical fertilizer. Among the treated plots, stem girth did not differ significantly, but all differed from the control $(\mathrm{P}=0.005)$.

\subsection{Yield of Eggplant}

Application of soil amendments resulted in significant increase in yield, ranging from $0.99 \mathrm{~kg}$ on the control plots to $7.09 \mathrm{~kg}$ on cow dung treated plots. Yield of eggplants on NPK and cow dung- treated plots differed significantly; however, yield on NPK and poultry manure-treated plots did not differ significantly (Table 2).

\section{Discussion}

The various soil amendments had significant effect on B.tabaci and A. gossypii scores. The significantly larger scores of these pests was due to better growth of eggplants on those plots which then supported large numbers of 
these pests. Organic manure is known to contain many minerals such as nitrates, phosphates (Rahman, 2000), magnesium and calcium (Dauda et al., 2005) and other minerals needed for healthy growth of plants. On the other hand, the chemical fertilizer used for the study contained only nitrogen, phosphorus and potassium. The high nitrogen content of organic manure and the fact that it contained other minerals enhanced better growth and therefore supported larger numbers of B. tabaci and A. gossypii. Studies by Zaini et al. (2013) and Jauset et al. (2000) reported that plants with high nitrogencontent increased egg survival and therefore supported large numbers of whiteflies. Contrary to this result, a study by Mochiah et al. (2011) on the effect of NPK and poultry manure on the pests of cabbage found no significant differences in the numbers of Plutella xylostella and Brevicoryne brassicae on plots treated with the two soil amendments.

Initially pests' numbers were small on all treated plots and the control, however, subsequent addition of the soil amendments resulted in increased pests' numbers, except on the control plots. Better vegetative growth of plants made them more attractive to feed on. Nutrient application and availability enhance vegetative growth, with large succulent leaves which are then able to support large numbers of phytophagous insects, including sap feeders. When soil is amended with organic and inorganic fertilizers, nitrogen contained in them is taken up by the plants in the form of nitrates and ammonium ions which plants use to form amino acids and other nitrogenous compounds such as chlorophyll (Jahn et al., 2004). This enhances vegetative growth, hence attracting larger numbers of insect pests.

The major pest recorded at fruit formation stage was the fruit and shoot borer Leucinodes orbonalis; however, they were totally absent from the control and NPK-treated plots. They were present only on the organic manure treated plots, in very small numbers. Ndereyimanal et al. (2013) recorded very small numbers of Brunjal shoot and fruit borer on plots treated with chemical fertilizer. A related study by Hosain (2009) reported that higher doses of NPK fertilizer increased the incidence of the pod borer Helicoverpa armigera compared to the control. This is an indication that increasing the nutrient content of the soil probably has the effect of increasing pests' numbers on crops.

Application of soil amendments had a significant effects on eggplants grown on cow dung amended soil since mean plant height was significantly taller than that of other treatments and the control. Similar results were recorded for number of leaves. It appears that organic fertilizer provided better medium of growth than chemical fertilizer. Poultry manure and cow dung amended soils produced taller plants than NPK-treated plots. Increased plant height on plots treated with organic manure was due to the presence of high phosphorus on the manure-treated plots ((Adilakshmi, 2008). According to Mochiah et al. (2011) 30- 50\% of phosphorus in animal manure is in organic form and must undergo mineralization into inorganic form to be available to plants. Results from our study, corroborates that of Aliyu (2000) that poultry manure positively affects vegetative development of garden eggs, thus improving the health and promoting growth of the plant. Organic manure is able to hold significant amounts of water compared to chemical fertilizer (Rakshit, 2009), thus making more water available to plants. This was even more significant due to the fact that the study was conducted during the period of low rainfall where soil moisture was low. Therefore the ability of organic manure to hold enough water made it readily available for nutrient uptake for growth.

Poultry and cow dung manure recorded larger numbers of leaves as a result of better availability of nutrients, an observation that was also asserted by Jahn et al. (2004) and Ulikan (2008). High nitrogen content in the soil enables plants to undergo vigorous growth. Soil amendments had significant effects on leaf area, with cow dung-amended plots recording larger leaf area than plants grown on NPK-amended soil, however, Mochiah et al. (2011) recorded larger leaf area on NPK-treated plots compared to poultry manure-treated plots. Increasing the nutrient content of the soil mainly increases leaf are index and light absorption, resulting in increased photosynthetic activity. This has been reported on crops such as lucerne (Medicago sativa) by Lemaire et al. (2005). Availability of soil nutrients and increased photosynthesis led to increased growth and yield. Cow dung, which recorded significant increase in plant height and leaf area also recorded the best yield. This shows that when fertility of the soil is improved it leads to increase in yield. Work done by Deshmukh and Takte (2007) on tomato revealed that application of NPK increased yield by $16 \%$. A related study by Mochiah et al. (2011) on the use of poultry manure as soil amendment recorded the best yield on the control plots. This was attributed to low pest infestation and percent leaf damage. Application of soil amendments to improve soil fertility has the effect of increasing crop production, however, excessive use of inorganic fertilizers can lead to improved vegetative growth making it more attractive to insect pest attack and increased pest damage resulting in reduction in yield.

\section{Conclusion}

Application of cow dung and poultry droppings to the soil significantly increased Bemisia tabaci and Aphis 
gossypii scores but had no significant effect on shoot and fruit borer Leucinodes orbonalis infestation. Application of soil amendments leads to improve crop yields, however, excessive use of inorganic fertilizer and organic manure increase vegetative growth and makes the plant more attractive to insect pests to cause damage to the plant. Our quest to increase crop production through nutrient application to the soil must be done together with pest management strategies in order to obtain the full benefits of soil amendments.

\section{References}

Adilakshmi, A. Korat, D. M., \&Vaishnav, P. R. (2008)Effect of organic manures and inorganic fertilizers on insect pests infesting okra. Karmataka Journal of Agricultural Science, 21(2), 287-289.

Alagarmalai, J., Selvaraj, P., \& Kuppusany, E. (2014).Antifeedant and insecticidal properties of selected plant extracts against Epilachna dodecastigma and Henosepilachna vigintioctopunctata (Coleoptera: Coccinellidae). http://file.scirp.org/Html/3-127001941792

Aliyu, L., Karikari, S. K., \& Ahmed, M. K. (1992). Yield and yield components of eggplant (Solanumgilo L.) as affected by date of transplanting, intra-row spacing and nitrogen fertilization. Journal of Agricultural Science and Technology, 2(1), 7-12.

Beckman, E. O. (1973). Organic vegetable farming.Luxury or necessity. Technical Communication of ISHA.29, 247.

Critchley, B. R. (1995). Manual for the integrated pest Management of diseases, insects, nematodes, and weeds of garden egg, okra, onion, peppers and tomato in BrongAhafo, Ghana. Natural Resources Institute (NRI), UK.

Dauda, S. N., Ajayi, F, A., \&Ndor, E. (2008) Growth and yield of water melon, (Citrullus lanatus) as affected by poultry manure application. Journal of Agricultural and Social Sciences, 4, 121-124.

Dauda, S. N., Aliju,L., \& Chiezey, U.F. (2005) Effect of variety, seedling age and poultry manure on growth and yield of garden egg (Solanum gilo L.). The Nigerian Academic Forum,9, 88-95.

Deshmukh, M. R., \&Takte, R. L. (2007) Effects of fertigation on growth and yield of tomato. Indian Journal of Entomology, 32(2), 181-183.

Goggin, F. L. (2007). Plant-aphid interaction: molecular and ecological perspectives: Current Opinion in Plant Biology, 10(4), 399-408. https://doi.org/10.1016/j.pbi.2007.06.004

Hossain, M. A., Prodham, M. Z. H., \&Haque, M. A. (2009). Response of NPK fertilizer on the incidence of pod borer, Helicoverpa armigera (Hubner) and grain yield of chicken pea. Bangladesh Journal of Scientific and Industrial Research, 44(1), 117-124. https://doi.org/10.3329/bjsir.v44i1.2720

Ibekwe, H. N., Ogbu, J. U., Uwalaka, O. A., Ngbede, S. O., \& Onyegbule, U. N. (2014). Efficacy of plant-derived insecticides for the control of insect pests of garden eggs (Solanum sp.) in Southeastern Nigeria.International Journal of Scientific and Technology Research, 3(8), 1-6.

Insaidoo,T.F.G., \&Quarshie-sam, S, J. (2007).Evaluation of the effects of hedgerow intercropping using Leucaena leucocephala and fertilizer application on growth and yield of garden eggs (Solanum melongena). Journal of Science and Technology, 27(2), 62-70. https://doi.org/10.4314/just.v27i2.33041

Jahn, G. C. (2004). Effects of soil nutrients in the growth, survival and fecundity of insect pests of rice.An overview and a theory of pests' outbreaks with consideration of approaches. Multitrophic interactions in soil and integrated Control' International Organization for Biological Control (IOBC) wprs Bulletin, 27(1), 115-122.

Jauset, A. M., Sarasua, M. J., Avilla, J., \& Albajes, R. (2000). Effect of nitrogen fertilization level applied on the greenhouse whitefly. Journal of Economic Entomology, 19(4), 255-261. https://doi.org/10.1016/S0261-2194(00)00016-8

Lemaire, G., Avice, J. C., Kim. T. H., \&Ourry, A. (2005). Development changes in sahoot N dynamics of lucerne (Medicago sativa L.) in relation to leaf growth dynamics as a function of plant density and hierarchical position within the canopy. Journal of Experimental Botany, 56, 935-943. https://doi.org/10.1093/jxb/eri084

Mochiah, M. B., Baidoo, P. K., \& Owusu-Akyaw, M. (2011). Influence of nutrient applications on insect population and damage to cabbage. Journal of Applied Biosciences, 38, 2564-2572.

Ndereyimanal, A., Praneethal, S., Pugalendhil, L., \& Hategekimana, A. (2013).Effect of spacing and 
fertigationon incidence of shoot and fruit borer (Leucinodes orbonalis Guenee) in eggplant (Solanum melongena L.) grafts. Indian Journal of Agricultural Science, 1(5), 102-105.

O’Neal, M. E., Landis, D. A., \& Isaacs, R. (2002).An inexpensive accurate method for measuring leaf area and defoliation through Digital Image Analysis.Journal of EconomicEntomology, 95(6), 1190-1194. https://doi.org/10.1603/0022-0493-95.6.1190

Owusu-Ansah, F. Afreh-Nuamah, K., Obeng-Ofori, D., \&Ofosu-Badu, K. G. (2001). Growth-promoting properties and yield effects of aqueous neem seed extract, biotic and karate on local garden eggs (Solanum integrifolium L.) in the field. Journal of Ghana Science Association, 3(3), 136-144. https://doi.org/10.4314/jgsa.v3i3.17776

Rahman, S. A. (2000). The place of organic manure in sustaining agricultural development tin Nigeria. Paper presented at Science Technology and Society National Workshop in Lafia, Nasarawa State, $11^{\text {th }}$ July 2000.

Rakshit, A., Sarkar, N. C., \&Sen, D. (2009). Influence of organic manures on productivity of two varieties of rice. Journal of Central European Agriculture, 9(4), 629-633.

Salifu, A. B. (1982). Biology of cowpea flower thrips and host plant resistance.MSc. Thesis.University of Ghana, Legon.

San Jose, R., Sanchez Mata, M. C., Camara, M., \& Prohens, J. (2014). Eggplant fruit composition as affected by the cultivation environment and genetic constitution. J. Sci. Food Agric., 94(13), 2774-2784. https://doi.org/10.1002/jsfa.6623

Shirley, S. (2000). Simple eggplant Kosher recipes from around the world. $9^{\text {th }}$ Edition, GefenPublishing House, Jerusalem, 91360, Israel, pp. 15.

Ulikan, H. (2008). Agronomic adaptation of some field crops. A general approach. Journal of Agronomy and Crop Science, 194, 169-179. https://doi.org/10.1111/j.1439-037X.2008.00306.x

Van Lenteren, J. C., \&Noldus, L. (1990). Whitefly-Plant relationship: Behavioral and ecological aspects. Whiteflies: their Bionomics, Pest Status and Management (July), 47-89.

Van Steenwyk, R. A., \& Barnett, W. W. (1985). Improvement of navel orangeworm (Lepidoptera; Pyralidae) egg traps. Journal of Economic Entomology, 78, 282-286. https://doi.org/10.1093/jee/78.1.282

Zaini, M. R., Rawi, C. S. M., \& Abu, H. (2013).Effect of nutrient and pre-infested Brunjal, Solanum melongena by whitefly and aphid population dynamics of whitefly, Bemisia tabaci. Journal of Agriculture, Forestry and Fishery, 2(1), 1-10. https://doi.org/10.11648/j.aff.20130201.11

\section{Copyrights}

Copyright for this article is retained by the author(s), with first publication rights granted to the journal.

This is an open-access article distributed under the terms and conditions of the Creative Commons Attribution license (http://creativecommons.org/licenses/by/3.0/). 